\title{
Improvement of international rail transportation of benzene between Ukraine and the European Union countries
}

\author{
Vasyl Gaba ${ }^{1}$, Tetiana Hrushevska ${ }^{1, *}$, Oleg Strelko ${ }^{2}$, Anna Kyrychenko ${ }^{2}$, Marina Rudyuk $^{1}$, and Ievgen Gusar ${ }^{1}$ \\ ${ }^{1}$ SUIT, Department of Management of Railway Commercial Activities, 29/18, Kotelnikov Street, Kyiv 03115 Ukraine \\ ${ }^{2}$ SUIT, Department of Transportation Technologies and Process Control Traffic, 29/18, Kotelnikov Street, Kyiv 03115 Ukraine
}

\begin{abstract}
It is considered the possibility of improvement of the international railway transportation of benzene and other related cargoes between Ukraine and the European Union countries for the carriage of these cargoes in tank containers. The volume of chemical cargo transportation to the EU countries to the rolling stock types for 2018 has been analyzed. The research of the effectiveness of organization of international transportation according to the criterion of the total hours of downtime by wagons under accumulation. The mathematical model of chemical cargoes transportation by wagons, wagon groups and container trains with the accumulation to the technical standards on the cargo diversions was elaborated. The models take into account the unevenness of the wagon arrivals to the accumulation points and observance of the number of wagons to the established norm. A comparison of the effectiveness of the two models of the organization of the chemical cargo delivery and it was defined a more effective version of transportation. It has been established that for more efficient using of the rolling stock and for the rolling stock circulation decreasing is the cargo transportation by trains which consist of cisterns or/and tank container carriages. The influence of the components of the rolling stock circulation and its value are analyzed. The research of the cost of benzene transportation in cisterns and tank containers for the individual diversions was studied. According to the research results the cost of benzene transportation by platforms of the railways ownership is less than twice in comparison to private cisterns and tankcontainers of the Ukrainian Railways fleet. These recommendations will improve the process of transportation and increase of volumes of international cargo by railroads between Ukraine and the EU countries.
\end{abstract}

\section{Introduction}

In today's conditions of globalization and the world economy integration Ukraine can not stay out of the world. Ukraine's entry into the world economy community gives access to international markets, expansion of trade and economic ties and improvement of transport and telecommunication systems.

Expansion of export of Ukrainian goods to the European market is one of the main factors for boosting the growth of Ukraine's gross domestic product, its economic prosperity and the population welfare.

In a scientific environment, specialists in transport technologies and organization of transportation by railroads have been constantly discussing the improving of international cargo delivery and different ways to organize trains along railroad tracks [1]. Two main variants are considered: the chemical cargo dispatch by wagons or wagon groups and by the composition of the container train to the standards during accumulation.

It is considered the cargo dispatch by wagons or wagon groups increases the rolling stock circulation due to downtime for wagons or the group wagons at the technical stations, waiting for accumulating and departure.
During the organization of the container train loading the transportation of chemical cargoes volume is increasing and the rolling stock circulation is decreasing.

It is difficult to study this problem without calculations due to the complexity and scale of the process, especially due to the uneven wagon arrivals to accumulation points. Therefore, the solution of the above task remains relevant nowadays.

\section{Literature review and problem statement}

An analysis of modern researches in the field of improving international rail transport shows that special attention is paid to the simulation of railway technological processes, which allows to take into account the technological carriage traffics characteristics and the development of mathematical models of the transport systems functioning. The development of a mathematical model for the bulk cargoes delivery by rail transport routes, which takes into account the interaction of production, transport and consumption, is proposed in the paper [2]. This model allows to solve a wide range of tasks that are faced by suppliers and consumers in the choice of railway transport, and is associated with the planning and operation of the stations. However, the

Corresponding author: gtm1520@gmail.com 
proposed mathematical model for the cargo delivery by rail routes does not take into account the cargo transportation by the container train and the influence of the main technological parameters which affect to the rolling stock circulation.

The development of a mathematical model for optimization of the sorting process is presented in [3]. This model allows temporarily to store freight wagons on a specially designed mixed rail, but does not include different variants of train departure.

International practice shows that in recent years, more than $60 \%$ of internationally transported cargoes were handled door-to-door. This gives the opportunity to optimize the transportation time, reduce the storage and transportation costs. International experience in improving the organization of intermodal freight transportation is revealed in [4]. The issue of developing approaches to determining the mode of transport involved in the transport process is addressed in [5].

The analysis of the influence of constituent elements on the value of the turnover of the freight wagon is analyzed in [6]. The parameters of the laws of their distribution are determined and the response function is obtained on the basis of the results of a complete factor experiment. However, this does not make it possible to determine the efficiency of sending rail freight by single wagons, groups of wagons and routes or container trains.

In [7], to improve the organization of transportation between different participants in the transport process, the authors propose to create an LCL export platform (LEP), using the blockchain concept to optimize LCL operations for international trade, by integrating and exchanging information between freight forwarding companies and their customers.

Development and active use of modern logistics concepts of multi-modal, inter-modal and combined transport are aimed at enhancement of the overall efficiency of cargo delivery processes, improvement of the package of services, provided in the process of motion from a supplier to a consumer. Comparison of external cost, assessment of economic benefits when using different modes of transport in the multi-modal chain was performed in [8].

A comprehensive business process and the model of the multi-modal transport system of container transportation of main based on the Multi-Agent technology for optimization and management of transport operations were presented in [9]. Optimal management in terms of using various kinds of transport in the container multi-modal system according to the criteria of cost, time and quality of cargo transport was considered on the method of dynamic programming [10].

For the plan for the formation of trains with the help of a mathematical model with fuzzy costs presented in [11] optimization of the process of forming (dismantling) warehouses at technical stations. The train formation plan determines the route, the frequency of trains, defines the requirements for trains, but does not take into account the departure of trains by accumulating to the norm of the receipt of wagons at points of accumulation.
The paper [12] analyzes the impact of systemic differences in rail transport between North America and Europe, provides a brief overview of relevant optimization models. Confirmed by the results that North American companies have lower transportation costs than European ones, due to the fact that North American models are mainly aimed at finding short distances for each wagon, and European ones - to a high level of accumulation to the standards of standards.

However, it should be noted that the above studies do not take into account the stochastic nature of the arrival of wagons in points of accumulation. There are no comprehensive models for assessing the efficiency of transportation by group or freight forwarding and freight transportation within the container train.

\section{The aim and methods of the study}

The aim of the work is to improve international rail transport and to conduct research on the most efficient rail freight shipments between Ukraine and EU countries.

The purpose of the article is to analyze and investigate the definition of methods of transportation of chemical cargo by rail between Ukraine and the countries of the European Union.

This goal is achieved by such commonly methods as analysis, synthesis, analogy, comparison, systems approach were used.

Scientific novelty. On the basis of the analysis and research, theoretical provisions and substantiated practical recommendations for increasing the volume of chemical cargo transportation to EU countries are formulated.

\section{Presentation of the main research materials with substantiation of scientific results}

During 2018, the European Union remained a key trading partner of Ukraine, with a share of trade in goods and services. The total volume of trade in goods and services between Ukraine and the EU in 2018 amounted to 49317 million dollars. The United States, and the volume of $41.1 \%$ of the total trade in goods and services between Ukrainian exports to the EU states was $\$ 23032$ million. USA, which is $14.3 \%$ more than last year.

The main importers of Ukrainian products during 2018 were: Poland (14.9\%), Italy (11.9\%), Germany $(11.3 \%)$, the Netherlands $(7.9 \%)$, Hungary $(7.4 \%)$, Spain $(6.2 \%)$, Great Britain $(4.9 \%)$.

The main goods of Ukrainian exports to the EU countries include: ferrous metals, ores, slag, grain crops, seeds and fruits of oilseeds, petroleum products, products of chemical related industries industry.

One of the products manufactured by industrial enterprises of Ukraine and exported to the EU countries is benzene - a colorless, volatile liquid with a characteristic smell. Density is $0.88 \mathrm{~g} / \mathrm{cm}^{3}$. Boiling point $-80.1{ }^{\circ} \mathrm{C}$. Melting point $-5.5{ }^{\circ} \mathrm{C}$. Benzene is a 
dangerous bulk load that according to the current classification of dangerous goods belongs to the third class (flammable liquids with the assignment of a special UN number 1114).

Today there are several fundamentally different methods of benzene producing:

1. Coking coal. This process was historically the first and served as the main source of benzene before the Second World War. Recently, the share of benzene obtained in this way is less than $10 \%$. It should be added that benzene, obtained from coal tar, contains a significant amount of thiophene, which makes such a benzene unsuitable for certain processes.

2. Catalytic reforming (aromisation) of gasoline fractions of oil. This process is the main source of benzene in the US. In Western Europe, Russia and Japan, in this way they receive $40-60 \%$ of the total amount of the compound. In this process, in addition to benzene, toluene and xylenes are formed. Considering that toluene is formed in quantities exceeding the demand for it, it is also partially processed into: benzene - by the method of hydrodealkylation; a mixture of benzene and xylenes - the method of disproportionation.

3. Pyrolysis of gasoline and heavier petroleum fractions. Up to $50 \%$ of benzene is produced by this method. Along with benzene, toluene and xylenes are formed. In some cases, all this fraction is sent to the dealkylation stage, where both toluene and xylenes are converted to benzene.

The production of benzene in Ukraine is carried out in two ways:

- at coking coal (method 1);

- in the processing of crude oil (methods 2, 3).

Benzene is one of the ten most important chemicals in the chemical industry and has a high demand for enterprises in the EU. It is widely used in industry, is the raw material for the production of polymers (plastics, rubber), drugs, dyes, pesticides, detergents, explosives, as a solvent for varnishes, and the like.

The main areas of benzene use are the production of ethylbenzene, cumene and cyclohexane. The share of these products accounts for about $70 \%$ of the world's consumption of benzene.

Delivery of benzene to destinations is carried out both by road and by rail. Transportation of benzene by road is carried out in special tank-vehicles. This transport is equipped with the necessary equipment, which ensures the safe transportation of cargo. This kind of transportation has its advantages in mobility, safety, door-to-door delivery, and can be effectively used in domestic traffic and in small quantities for short distances.

Considering the small volume of international traffic by road, we will not determine the cost of such transportation. Comparison of costs for delivery of goods by road and tank-containers of the complete door-todoor supply chain between the sender and the recipient is specified in the contract and it is confidential information. Therefore, the calculations are made only by rail from the departure station to the destination station.
Transportation of large quantities of benzene over considerable distances is usually carried out by rail transport with subsequent unloading or overloading to other modes of transport.

Since benzene is an extremely flammable liquid with a flash point of $11.630 \mathrm{C}$ in accordance with DSTU 4500-3: 2008 "Cargo is dangerous. Classification ", it is classified as dangerous goods of the 3rd grade of danger, and the average degree of danger (packing group II) has been assigned to indicators of flash temperature and boiling temperature.

Transportation of benzene by rail is carried out in railway cisterns model 15-1443-07, 15-5103-6B, 15$150-03 \mathrm{~B}, 15-1527$. In internal traffic, benzene is transported in accordance with the Rules for the carriage of dangerous goods, the Rules for the carriage of bulk cargoes, and in international traffic also in accordance with the "Regulations for the Transport of Dangerous Goods" (Annex 2 to SMGS). Analysis of the transportation of benzene in all types of connections (domestic, transit, exports to the EU and the Russian Federation) is presented in Table 1.

Table 1. Benzene transportation to EU countries in 2018

\begin{tabular}{|c|c|c|c|c|}
\hline $\begin{array}{l}\text { Country of } \\
\text { destination }\end{array}$ & Export & $\begin{array}{c}\text { Internal } \\
\text { connection }\end{array}$ & Transit & Total \\
\hline Poland & 31900 & & 6276 & 38176 \\
\hline Slovakia & 46280 & & 156 & 46436 \\
\hline Netherlands & 40194 & & & 40194 \\
\hline Italy & 19627 & & & 19627 \\
\hline Czech Rep. & 8034 & & & 8034 \\
\hline Germany & 4498 & & & 4499 \\
\hline Ukraine & & 25637 & & 25637 \\
\hline $\begin{array}{l}\text { Russian } \\
\text { Federation } \\
\end{array}$ & 2325 & & & 2326 \\
\hline \begin{tabular}{|l} 
Total \\
\end{tabular} & 152859 & 25637 & 6431 & 184927 \\
\hline
\end{tabular}

Diagram of imported petrol to the EU countries for 2018 (export) is shown in Figure 1.

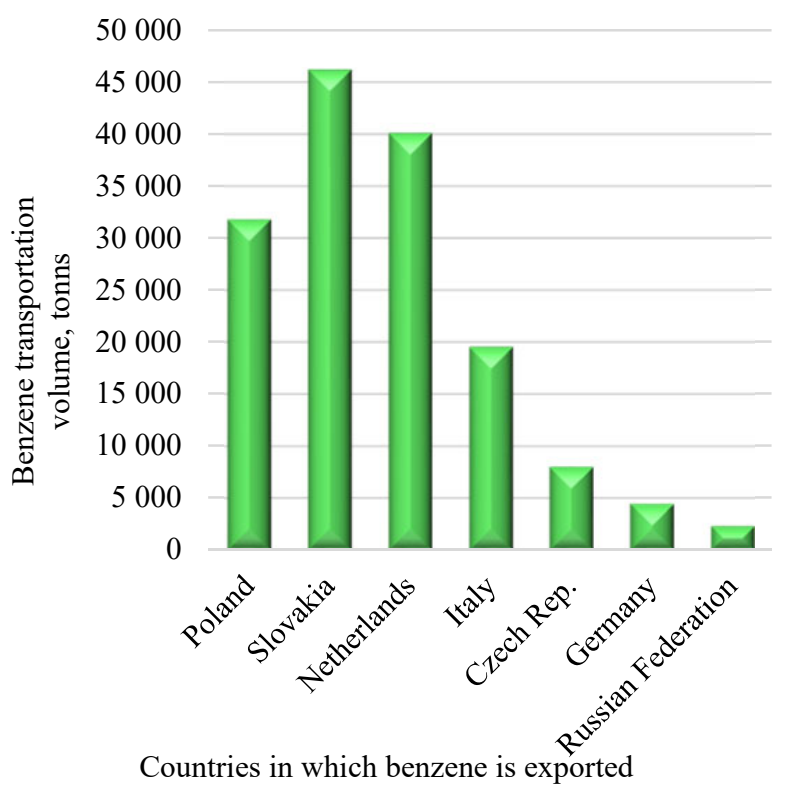

Fig. 1. Benzene transportation to EU countries in 2018 (export) 
As it can be seen from the table and diagram, the benzene export from Ukraine is $83 \%$ or 152859 tons and is advantageous for it. Comparing five months of 2019 to the same period in 2018, benzene export increased by 5917 tons and amounted to 7,357 tons. The main dispatchers of benzene for export are PJSC
"Zaporizhkoks", PJSC "AKXZ", PJSC "ArcelorMittal", PJSC "DKHZ", PJSC "MK Azovstal" and others. An analysis of the use of rolling stock for the carriage of benzene in 2018 and the five months of 2019 is given in Table 2.

Table 2. Analysis of the use of rolling stock for the transportation of benzene

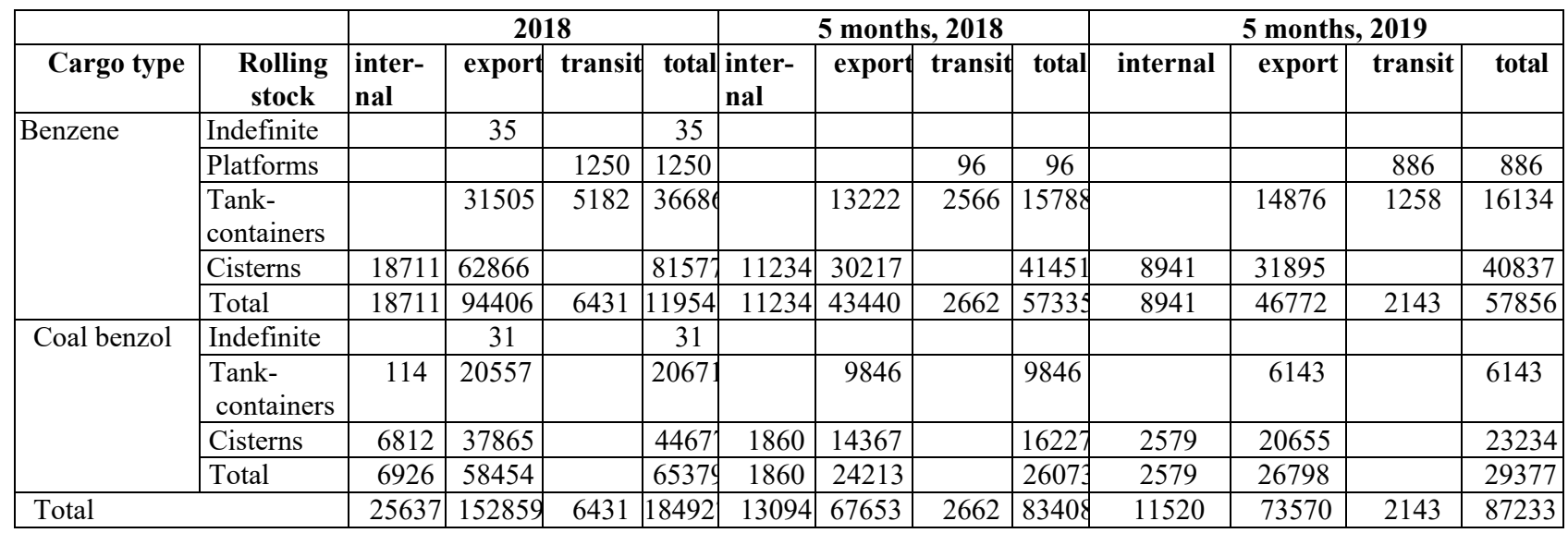

The cargo is delivered to the border transmission station, where the permutation of $1520 \mathrm{~mm}$ rail wagons is carried out on the $1435 \mathrm{~mm}$ railroad tracks, or when transported by tank-containers, they are trans-loaded from the platform of $1520 \mathrm{~mm}$ to the platform of $1435 \mathrm{~mm}$. When transporting benzene to Poland via the border crossing of Izov-ex Khrubushov-eks, the cargo, both in cisterns and in tank-containers, follows a 1520 $\mathrm{mm}$ track deep into Poland almost $400 \mathrm{~km}$ to the station 'Slavkiv LHS.
The technology of the transfer of cargoes at border transmission stations with the EU countries is determined by the protocols of meetings on harmonization of the estimated volumes and conditions of transportation of foreign trade by rail by rail between the railways administrations.

Figure 2 shows the use of rolling stock by type during 2018.

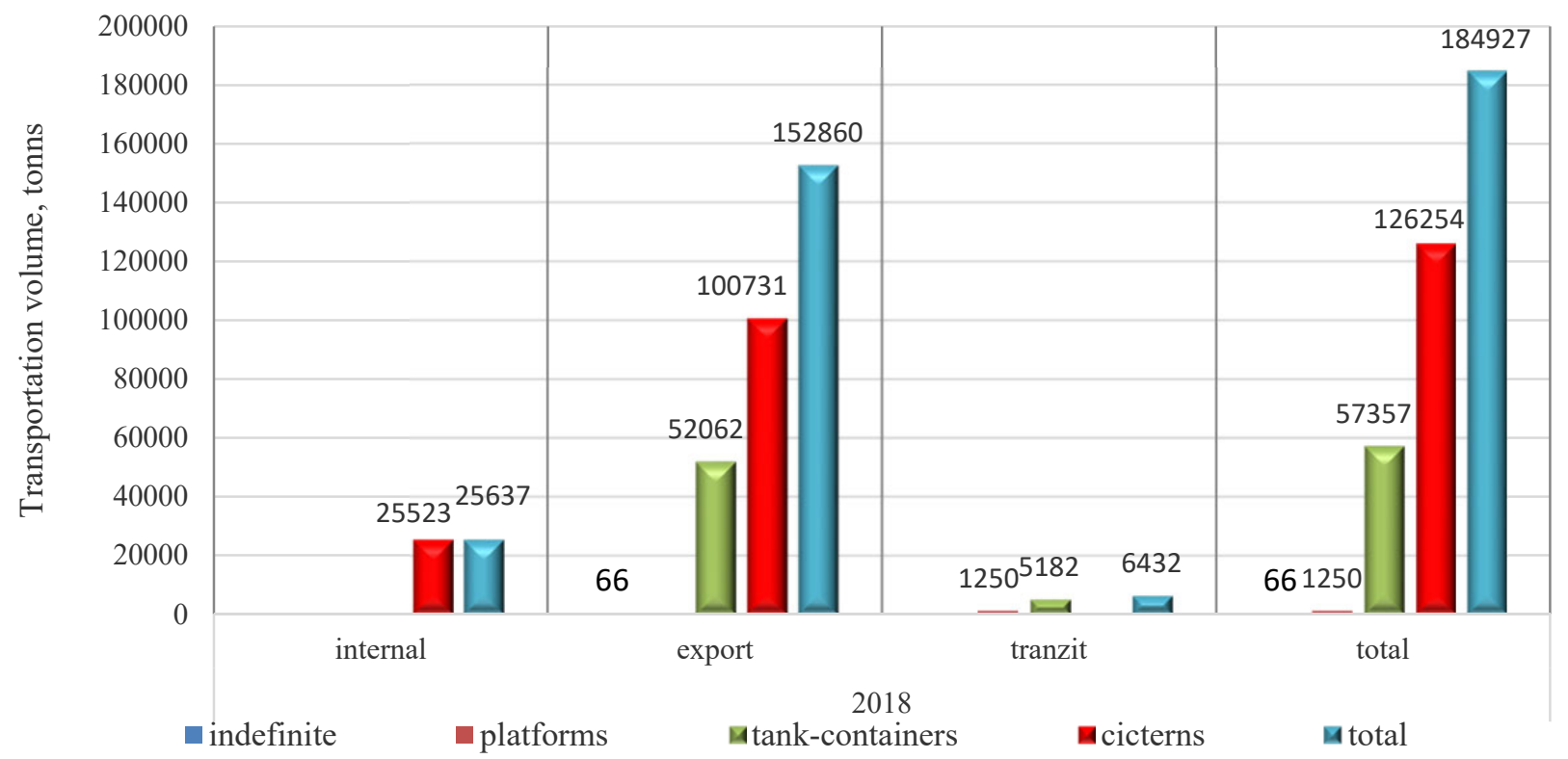

Fig. 2. Analysis of the use of rolling stock by type of rolling stock during 2018

From the schedule it is possible to conclude that $66 \%$ of benzene is exported from Ukraine and only $34 \%$ in tank containers on fitting platforms in Ukraine. In domestic transport, cisterns are used for transporting benzene by rail.
The shortage of rail cisterns due to the deadline for their operation and the lack of funds for the production of new, high tariffs for transportation in cisterns leads to the search for alternatives for the transportation of benzene. The modern kind of transportation of benzene is the tank- 
containers of such models EMT5, EMT6, EMKD. The characteristic difference between such containers is that they have a standard size of 30 feet in length, but the frame is standard for a 20 foot container. In some sources, their name is called "SWAP-container". To transport such containers it is necessary to involve the corresponding platforms in the length of $60-80$ feet: railway fitting platforms of such models -13-4117, 13-7024, 13-1796-04. Load-carrying capacity of platforms - 70-72 tons, length of axles of carriages $-19500-25690 \mathrm{~mm}$.

For the buyer of cargo, one of the main factors is the assessment of the cost of delivery of cargo [12]. Costs are considered for each delivery scheme depending on the established baseline conditions. Total costs to be borne by the seller or the buyer include expense groups:

$$
P_{1} P_{2}=P_{p v}+P_{l}+P_{t}+P_{c}+P_{r}+P_{f}+P_{s},
$$

where $P_{p v}$ - expenses for preparation of cargo dispatch, $\mathrm{UAH}$;

\section{$P_{l}$ - complex of expenses for loading, UAH;}

$P_{t}$ - payment for transportation taking into account the cost of additional services for cargo handling, UAH;

$P_{c}$ - expenses for customs clearance of cargo at departure of cargo for export, UAH;

$P_{r}-$ expenses for rental of rolling stock (cisterns, tank-containers and fitting platforms);

$P_{f}$ - expenses for forwarding services, UAH;

$P_{s}$ - other shipping costs.

The costs of the seller and the buyer are determined depending on the basic conditions when entering into a foreign trade contract. It is they that influence the formation of the composition of the costs of organizations, and, accordingly, the financial result of export-import operations.

Each expense metric consists of sub-groups of individual expenditures. Expences for preparing the cargo departure are calculated on the basis of the cost of one ton of cargo. For the most part, this is done by the sender of the goods and may include these costs in the cost of the goods.

Complex of expenses on load is determined by the formula:

$$
P_{l}=P_{l}^{m}+P_{s s},
$$

where $P_{l}^{m}$ - the costs of the main (leased or private) rolling stock loading; $P_{s s}$ - survey services.

The cost of customs clearance during the cargo dispatch for export is determined by the formula:

$$
P_{c}=P_{c p}+P_{c d}+P_{d},
$$

where $P_{c p}$ - customs payments, UAH;

$P_{c d}-$ customs duties, UAH;

$P_{d}$ - registration of the customs declaration, UAH.

Costs of cargo delivery are calculated according the requirements of tariff policies and additional documents of the state administrations of the country of the cargo transporter.

The cost of renting cisterns or fitting platforms is made with the rolling stock owners.

Expeditor expenses for transportation of goods for export are determined by the interest rate on the cost of delivery of goods, which is indicated in the annex to the contract for provision of services in freight forwarding.

During transportation, there may be certain costs not provided for by the terms of transportation (expenses from improperly executed documents, technical problems of rolling stock, etc.). Such costs are considered on the basis of specific situations and, accordingly, completed documents, and sometimes in court.

The study of the cost of transportation of benzene in cisterns and tank-containers took place in one of the directions of Avdeyivka-Izov-Avdeyivka:

1. A private cistern of 60 tons load capacity - the cost of transportation of the loaded and empty cistern for infusion amounted to $88950 \mathrm{UAH}$. for a wagon. The price does not include the fee for using a private wagon.

2. Cistern of the UZ fleet with a carrying capacity of 60 tons - the cost of transportation on the same route was $96920 \mathrm{UAH}$. for a wagon. The cost includes the fare for transportation and the payment for the use of the wagon.

3. Private tank-containers with their transportation on the platforms of "UTSTS Liski" (UZ) - the loading of two tank-containers of total weight of 60 tons makes for the specified route 36880 UAH per wagon. The cost includes the payment for the transportation and using of the platform without paying for using of tank-containers.

The analysis of the calculations shows the efficiency of benzene transportation in tank-containers and such transportation is cost-effective for enterprises receiving benzene. Transportation of benzene in cisterns, taking into account the constant increase of the cost of transportation for most of the recipient companies, is unprofitable.

Raising tariffs for rail freight transportation within Ukraine by $15 \%$ from October 31, 2017 has had a very negative impact on the financial situation of chemical enterprises, as these costs affect the cost of finished goods and raw materials supplies.

The advantage of transporting benzene in tankcontainers is obvious, but the constraining factor is the limited number of railway fitting platforms of the abovementioned brands.

The enterprises of Poland and partly Slovakia for the transportation of benzene from Ukraine use container containers in the amount of 90 units and there is an opportunity to increase them to 110 , but the lack of longstanding fitting platforms of the Ukrainian railways park does not allow to increase the volumes of transportation.

The appointment of Ukrzaliznytsya JSC from 1 April 2019 was a positive factor in increasing the efficiency and, thus, increasing container traffic in the UkrainePoland interconnection, by heading the container train along the route Nizhnedneprovsk-Vuzol of the Pridneprovska railroad-Izov-export of the Lviv railway. The formation of a container train is carried out from the groups of wagons by departure from the stations 
Mariupol-sorting, Avdeyivka and Sartana of the Donetsk railway and Zaporozhye-Live and Pravda Prydniprovska railway. Changing this container train actually reduces the time spent fitting platforms on routes and thus increases their circulation.

An important factor in increasing the volumes of transportation of benzene and other chemical cargo from Ukraine to the EU countries is the efficient use of rolling stock due to the reduction of the circulation of wagons and the shortening of its delivery time.

Intensification of the rolling stock circulation allows to increase the volume of transportation without increasing the wagon fleet, thereby reducing capital costs on the rolling stock. According to the statistics of recent years, the largest part of the circulation is the total wagon downtime under load operations at loading / unloading points - about $49 \%$, the wagon downtime at technical and intermediate stations is about $37 \%$ and in the railway carriage is $14 \%$. In fig. 3 shows the distribution of factors affecting the rolling stock circulation.

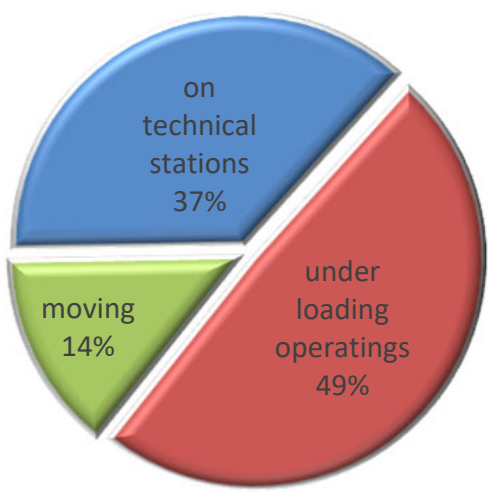

Fig. 3. Distribution of influencing factors on the rolling stock circulation

Transportation of benzene and other chemical cargo from Donetsk and Pridneprovska railways stations can be carried out by single wagons, groups of wagons and routes or container trains, the model of which is presented in Fig. 4, 5 respectively.

\section{Model of chemical cargo transportation by carriage and carriage groups dispatch}

$$
\mathrm{N}_{\mathrm{n}}
$$

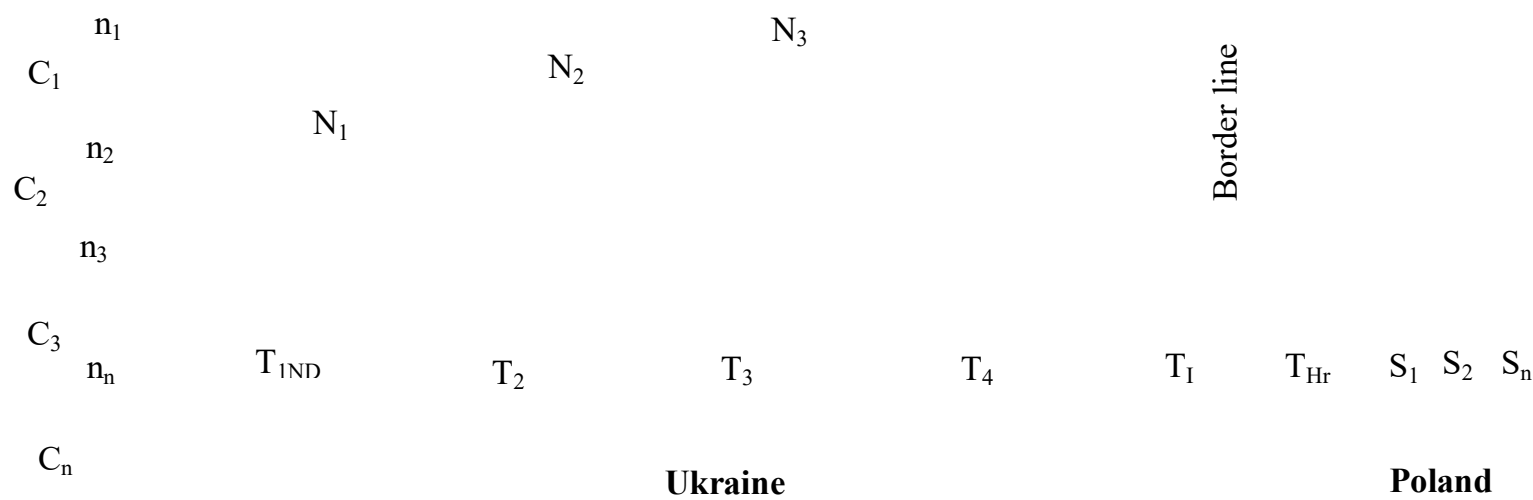

Fig. 4. Transportation of chemical goods by Donetsk and Prydniprovska railway by carriage and carriage groups dispatch

\section{Model of the chemical cargo transportation by the container train}

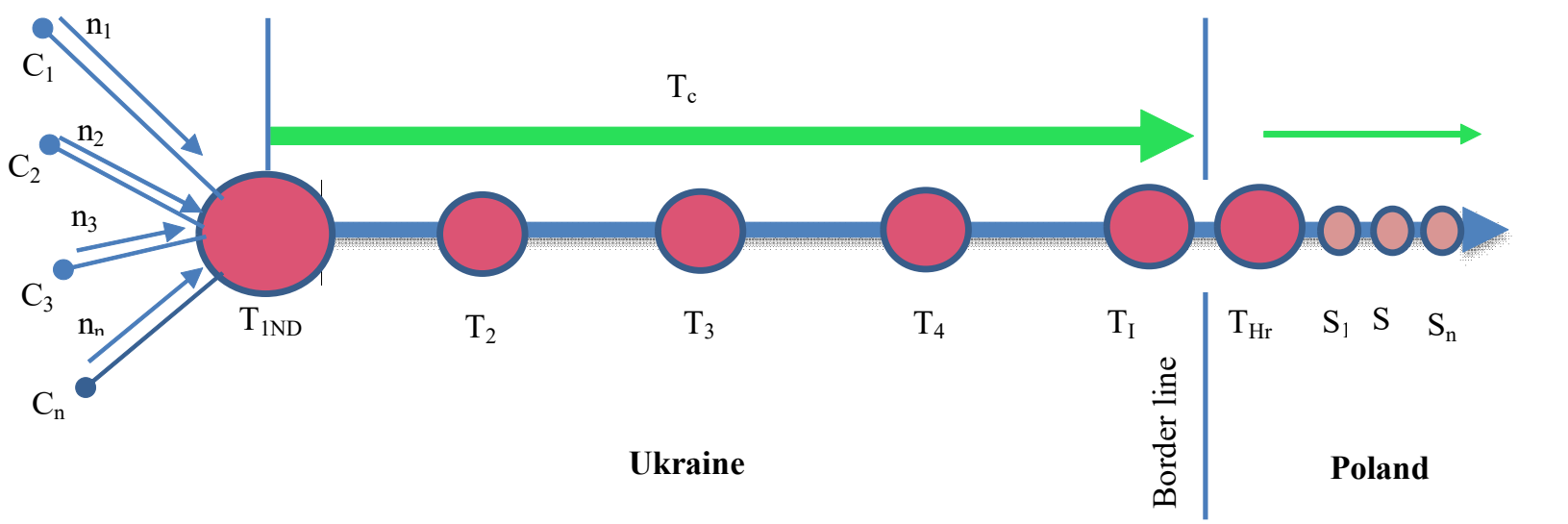

Fig. 5. Transportation of the container train on the route Nizhnedneprovsk-Vuzol - Izov export

where $\mathrm{C}_{1}, \mathrm{C}_{2}, \mathrm{C}_{3}, \mathrm{C}_{\mathrm{n}}$ - loading and unloading stations;

$\mathrm{T}_{1 \mathrm{ND}}, \mathrm{T}_{2}, \mathrm{~T}_{3}, \mathrm{~T}_{\mathrm{n}}, \mathrm{T}_{\mathrm{I}}, \mathrm{T}_{\mathrm{Hr}}-$ technical stations;

$\mathrm{S}_{1}, \mathrm{~S}_{2}, \mathrm{~S}_{\mathrm{n}}-$ stations located in Poland; $\mathrm{n}_{1}, \mathrm{n}_{2}, \mathrm{n}_{3}, \mathrm{n}_{\mathrm{n}}$ - transportation of goods by group or single carriages;

$\mathrm{T}_{\mathrm{c}}$ - transportation of goods in the container train. 
To calculate the travel time of a wagon, apply a three-member formula:

$$
\theta=\frac{1}{24} \cdot\left(\frac{(1+\alpha) l_{v}}{V_{d}}+\frac{(1+\alpha) l_{v}}{L_{t}} \cdot t_{t}+K_{m} \cdot t_{v}\right)
$$

where $l_{v}$ - the trip of the wagon in the loaded condition, $\mathrm{km}$;

$$
\alpha \text { - coefficient of empty running; }
$$

$V_{d}$ - average vehicle speed, $\mathrm{km} / \mathrm{h}$;

$t_{t}$ - average wagon downtime at the technical stations during dispatching of wagons or wagon groups and container train, $\mathrm{h}$;

$L_{t}$ - "arm carriage" - the average distance between the technical stations, where trains are not subject to proof or subject to reorganization, $\mathrm{km}$;

$K_{m}$ - coefficient of local work;

$t_{v}$ - average wagon downtime under a loading operation, $h$.

When considering each model of the magnitude $K_{m}$ and $\alpha$ assume equal to 1 .

Formula (4) allows to calculate the comparison of spent time spent on delivery of chemical cargoes by carriage by rail and container trains accumulated to the norm of the compositions by the direction of carriage by rail.

The conducted researches revealed that during carriage by group and single carriages the carriage turnover is 15 days, that is, two flights per month, and for transportations in a container train for up to 10 days, or three flights. Container trains are most effective because the wagons do not idle at the technical stations in anticipation of accumulation and shipment. Moving container trains gives an opportunity to increase the volume of transportation of chemical goods, including benzene to the EU countries in 1,5 times.

An important role in the organization of international transportation, in particular, and benzene, is given to freight forwarding or carrier companies, which can organize such transportation more efficiently at the least cost. One such company is "GalTrans", Lviv, which has been operating in the transport services market for 20 years and is one of the leaders in the organization of cargo transportation by railways in the western direction. The company provides services to companies in Poland, Slovakia, Germany in the organization of international cargo transportation, including benzene. The experience of the company proves its efficiency in the market of international forwarding services. "GalTrans" is a reliable partner between the dispatcher, the carrier and the consignee.

In our opinion, one of the restraining factors of the increase of the circulation of existing transportations in tank-containers and thus an increase in the volumes of transportation for the export of benzene is the poor security of goods on the Donetsk and Dnieper railways of Ukraine, which leads to frequent theft of spare parts both platforms and tank-containers. As a result of these thefts, wagons are idle in anticipation of replacement of spare parts for several weeks. Equally important factor affecting the turnover of wagons, and thus reducing the volumes of transportation of benzene in tank-containers, is the lack of work of the appropriate station personnel of the UZ who do not show any damage to the rolling stock during transportation or at the arrival stations, and the breakage The wagons are already on the access roads of the recipient. Thus, a wagon with a detected malfunction can no longer return to the arrival station for repair, and again, the idling time for repair during weeks.

\section{Conclusion}

To improve international transportation of benzene and related cargoes by rail between Ukraine and the countries of the European Union in the article:

- a mathematical model of transportation of chemical goods by wagon (group) shipments and transportation of a container train has been developed for accumulation to the norm of compositions in the direction of transportation. The most effective variant of transportation of chemical goods - within the container train;

- the research of the cost of transportation of benzene in cisterns and tank-containers in separate directions was carried out, as a result of which it is proposed to carry out a phased transition to the transport of benzene in tank containers, and for the more efficient use of rolling stock - to reduce the turnover of wagons by transporting wagons in container trains;

- the calculation of estimation of cost of delivery of loads by cost groups is resulted. The above suggestions will give an opportunity to increase the volumes of transportation of chemical goods in 1,5-2 times and reduce expenses for these transportation;

- it is proposed to increase the production of longstanding fitting platforms for tank-containers, attracting investors and the most professional forwarding / carrier companies working in the provision of transport services in the international market.

These recommendations will improve the transportation processes and increase of volumes of international cargo by railroads between Ukraine and the EU countries.

\section{References}

1. V. Matsiuk, V. Myronenko, V. Horoshko, A. Prokhorchenko, T. Hrushevska, R Shcherbyna, N. Matsiuk, J. Khokhlacheva, I. Biziuk, N. Tymchenko Improvement of efficiency in the organization of transfer trains at developed railway nodes by implementing a «flexible model» Eastern-European Journal of Enterprise Technologies: Control processes, 2/3(98), 32-39. (2019).

2. N. Shramenko, V. Shramenko Mathematical model of the logistics chain for the delivery of bulk cargo by rail transport. Naukovyi Visnyk Natsionalnoho Hirnychoho Universytetu, 5, 136-141. (2018). 
3. M. Bohlin, S. Gestrelius, F. Dahms, M. Mihalák, H. \& Flier. Optimization Methods for Multistage Freight Train Formation. Transportation Science, 50(3), 823-840. doi: 10.1287/trsc.2014.0580. (2016).

4. Bontekoning, Y. M., Priemus H. Breakthrough innovations in intermodal freight transport. Transportation Planning and Technology. 27 (5), 335-345. (2004).

doi: $10.1080 / 0308106042000273031$

5. Konings R., Priemus H., Nijkamp P The Future of Intermodal Freight Transport. Operations, Design and Policy. Transport economics, management and policy. Series Editor: Kenneth Button,University Professor, School of Public Policy, George Mason University, USA, 135-151. (2008)

6. G. Peresta, T. Bolvanovskaya Analiz vplyvu skladovykh elementiv na velychynu oborotu vantazhnoho vahona. Zbirnyk naukovykh prats DNUZT im. akad. V.Lazariana. Vyp. 1. P. 75 - 77. (2011) [in Ukrainian].

7. Tan A. W. K., Zhao Y., Halliday T. A Blockchain Model for Less Container Load Operations in China International Journal of Information Systems and Supply Chain Management. 11(2), 39-53. (2018). doi: https://doi.org/10.4018/ijisscm.2018040103

8. Kos S., Vukić L., Brčić D. Comparison of External Costs in Multimodal Container Transport Chain
PROMET - Traffic\&Transportation, 29 (2), 243. (2017). doi: 10.7307/ptt.v29i2.2183

9. Liu T., Zheng G. Study Logistics Architecture for Grain Container Multimodal Transport Based on Multi-Agent Proceedings of The 7th International Conference on Computer Engineering and Networks - PoS(CENet2017). (2017). doi: 10.22323/1.299.0049

10. Hao C., Yue Y. Optimization on Combination of Transport Routes and Modes on Dynamic Programming for a Container Multimodal Transport System Procedia Engineering, 137, 382-390. (2016). doi: 10.1016/j.proeng.2016.01.272

11. M. Yaghini, M. Momeni, M. \& Sarmadi, A hybrid solution method for fuzzy train formation planning. Applied Soft Computing, 31, 257-265. doi: 10.1016/j.asoc.2015.02.039. (2015).

12. Uwe Clausen, Robert Voll A comparison of North American and European railway systems. Why Europe needs particular optimization models for railway freight traffic. Eur. Transp. Res. Rev, 5, 129-133. DOI 10.1007/s12544-013-0090-4. (2013).

13. Nagornyi Ye. Transportno-ekspedytorska diialnist Ye.V. Nahornyi, D.V. Lomotko, N.Iu. Shramenko ta in.: pidruchnyk. - Kh.: KhNADU, 2012. - 352 s. [in Ukrainian] 